\title{
Non-parametric Approaches to Education and Health Expenditure Efficiency in OECD Countries ${ }^{1}$
}

\author{
António Afonso ${ }^{2}$ and Miguel St. Aubyn ${ }^{3}$
}

January 2004

\begin{abstract}
We address the efficiency of expenditure in education and health sectors for a sample of OECD countries by applying two alternative non-parametric methodologies: FDH and DEA. Those are two areas where public expenditure is of great importance so that findings have strong implications in what concerns public sector efficiency. When estimating the efficiency frontier we use both measures of expenditure and quantity inputs. We believe this approach to be advantageous since a country may well be efficient from a technical point of view but appear as inefficient if the inputs it uses are expensive. Efficient outcomes across sectors and analytical methods seem to cluster around a small number of core countries, even if for different reasons: Finland, Japan, Korea and Sweden.
\end{abstract}

JEL: I18, I21, I28, H51, H52, C14

KEYWORDS: expenditure and education, expenditure and health, expenditure efficiency, production possibility frontier, FDH, DEA

\footnotetext{
${ }^{1}$ We are grateful to Manuela Arcanjo, Rigmar Osterkamp, Álvaro Pina, Ludger Schuknecht, Léopold Simar and Guido Wolswijk for helpful comments. Any remaining errors are the responsibility of the authors. The opinions expressed herein are those of the authors and do not necessarily reflect those of the author's employers.

${ }^{2}$ ISEG/UTL - Technical University of Lisbon, CISEP - Research Centre on the Portuguese Economy, R. Miguel Lupi 20, 1249-078 Lisbon, Portugal, email: aafonso@iseg.utl.pt.

${ }^{3}$ ISEG/UTL - Technical University of Lisbon, UECE - Research Unit on Complexity in Economics, R. Miguel Lupi 20, 1249-078 Lisbon, Portugal, email: mstaubyn@ iseg.utl.pt.
} 


\section{Contents}

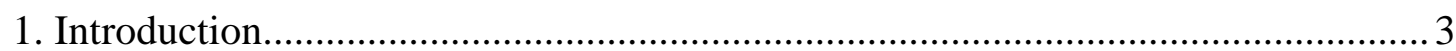

2. Literature on spending efficiency and motivation................................................. 4

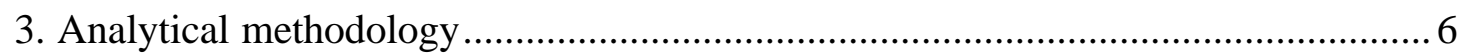

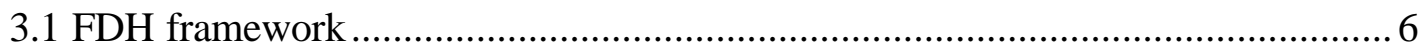

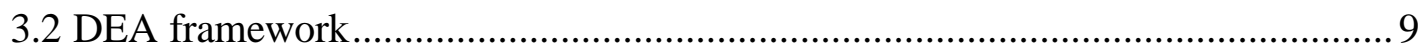

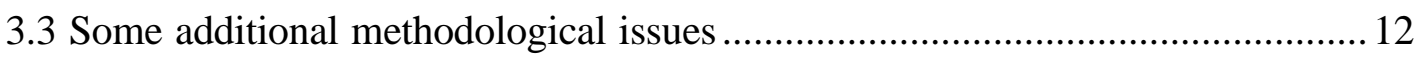

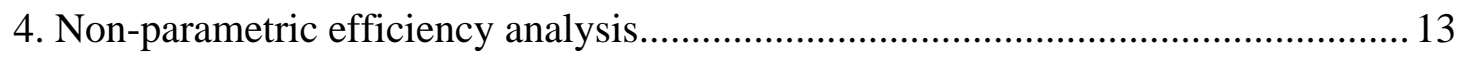

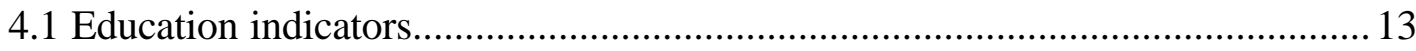

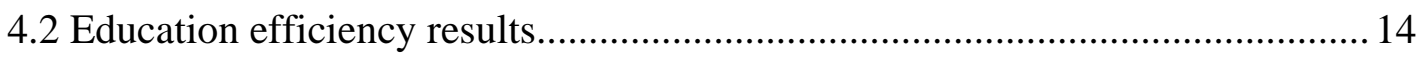

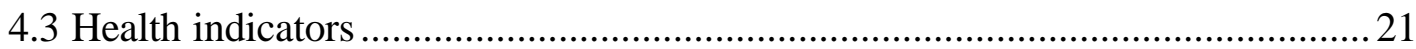

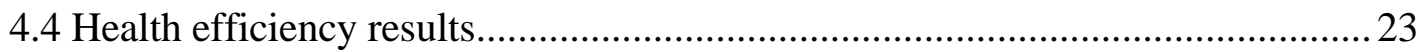

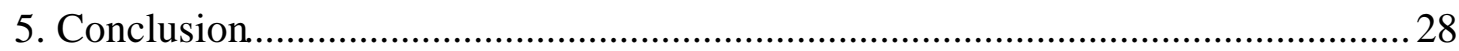

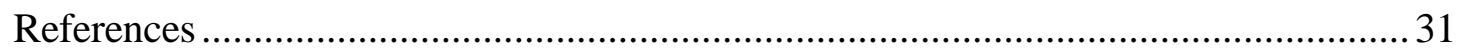

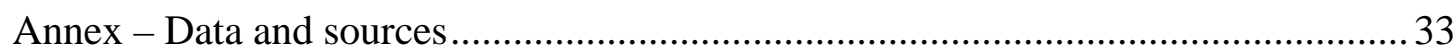




\section{Introduction}

The debate in economics on the proper size and role of the state is pervasive since Adam Smith. Nevertheless, the proper measurement of public sector performance, particularly when it concerns services provision, is a delicate empirical issue and the literature on it, particularly when it comes to aggregate and international data is still limited. This measurement issue is here considered in terms of efficiency measurement. In our framework, we compare resources used to provide certain services, the inputs, with outputs. Efficiency frontiers are estimated, and therefore inefficient situations can be detected. As the latter will imply the possibility of a better performance without increasing allocated resources, the efficiency issue gives a new dimension to the recurring discussion about the size of the state.

Although methods proposed and used here can be applied to several sectors where government is the main or an important service provider, we restrict ourselves to efficiency evaluation in education and health in the OECD countries. These are important expenditure items everywhere and the quantities of public and private provision have a direct impact on welfare and are important for the prospects of economic growth. OECD countries were chosen because data for these countries were collected following the same criteria and provided by the OECD itself, both for education and health. Also, this sample is not too heterogeneous in wealth and development terms, so that an efficiency comparison across countries is meaningful.

Our study presents two advances in what concerns the recent literature on the subject. First, when estimating the efficiency frontier, we use quantity inputs, and not simply a measure of expenditure. We consider this procedure to be advantageous, as a country may well be efficient from a technical point of view but appear as inefficient in previous analysis if the inputs it uses are expensive. Moreover, our method allows the detection of some sources of inefficiency (e. g. due to an inappropriate composition of inputs). Second, we do not restrain to one sole method, but compare results using two methods. To our knowledge, Data Envelopment Analysis has not yet been used in this context. This is a step forward in what concerns the evaluation of result robustness. 
The paper is organised as follows. In section two we briefly review some of the literature on spending efficiency. Section three outlines the two non-parametric approaches used in the paper and in section four we present and discuss the results of our non-parametric efficiency analysis. Section five provides conclusions.

\section{Literature on spending efficiency and motivation}

Even when public organisations are studied, this is seldom done in an international and more aggregate framework. International comparisons of expenditure performance implying the estimation of efficiency frontiers do not abound. To our knowledge, this has been done by Fakin and Crombrugghe (1997) and Afonso, Schuknecht and Tanzi (2003) for public expenditure in the OECD, by Clements (2002) for education spending in Europe, by Gupta and Verhoeven (2001) for education and health in Africa, and by St. Aubyn (2002, 2003) for health and education expenditure in the OECD. All these studies use Free Disposable Hull analysis and the inputs are measured in monetary terms. Using a more extended sample, Evans, Tandon, Murray and Lauer (2000) evaluate the efficiency of health expenditure in 191 countries using a parametric methodology.

In this paper we are particularly interested in education and health expenditure, two important public spending items. For instance, for some EU countries, spending in these two categories, plus R\&D, accounted for between 10 and 15 per cent of GDP in 2000. Public expenditure in these items increased during the last 20 years with particular emphasis in countries where the levels of intervention were rather low, such as Portugal and Greece. ${ }^{4}$

Table 1 summarises some data on education and health spending in OECD countries. In 2000, education spending varied between 4 and 7.1 percent of GDP within OECD countries. This expenditure is predominantly public, and particularly in European countries (92.4 percent of total educational expenditure is public in the EU). Total expenditure on health is usually higher than expenditure on education, and it averaged 8 percent of GDP in the OECD. Public expenditure in health is usually more than half

\footnotetext{
${ }^{4}$ See EC (2002).
} 
of total expenditure, and it averaged 72.2 percent of total in the OECD. The US are a notable exception - being the country where health spending is relatively higher (13.1 of GDP) and were private spending is more important (55.8 per cent of total).

Table 1. Public and total expenditure on education and on health, 2000

\begin{tabular}{|c|c|c|c|c|}
\hline & $\begin{array}{c}\text { Public expenditure } \\
\text { on education } \\
(\% \text { of total } \\
\text { expenditure }) \\
\end{array}$ & $\begin{array}{c}\text { Total expenditure } \\
\text { on education } \\
(\% \text { of GDP })\end{array}$ & $\begin{array}{c}\text { Public expenditure } \\
\text { on health } \\
(\% \text { of total } \\
\text { expenditure }) \\
\end{array}$ & $\begin{array}{c}\text { Total expenditure } \\
\text { on health } \\
(\% \text { of GDP) }\end{array}$ \\
\hline Australia & 75.9 & 6.0 & 68.9 & 8.9 \\
\hline Austria & 94.2 & 5.7 & 69.4 & 7.7 \\
\hline Belgium & 93.3 & 5.5 & 72.1 & 8.6 \\
\hline Canada & 80.6 & 6.4 & 70.9 & 9.2 \\
\hline Czech Republic & 90.0 & 4.6 & 91.4 & 7.1 \\
\hline Denmark & 96.0 & 6.7 & 82.5 & 8.3 \\
\hline Finland & 98.4 & 5.6 & 75.1 & 6.7 \\
\hline France & 93.8 & 6.1 & 75.8 & 9.3 \\
\hline Germany & 81.1 & 5.3 & 75.0 & 10.6 \\
\hline Greece & 93.8 & 4.0 & 56.1 & 9.4 \\
\hline Hungary & 88.3 & 5.0 & 75.5 & 6.7 \\
\hline Iceland & 91.1 & 6.3 & 83.7 & 9.3 \\
\hline Ireland & 90.6 & 4.6 & 73.3 & 6.4 \\
\hline Italy & 92.2 & 4.9 & 73.4 & 8.2 \\
\hline Japan & 75.2 & 4.6 & 78.3 & 7.6 \\
\hline Korea & 61.0 & 7.1 & 44.4 & 5.9 \\
\hline Luxembourg & na & na & 87.8 & 5.6 \\
\hline Mexico & 85.9 & 5.5 & 47.9 & 5.6 \\
\hline Netherlands & 91.6 & 4.7 & 63.4 & 8.6 \\
\hline New Zealand & na & na & 78.0 & 8.0 \\
\hline Norway & 98.7 & 5.9 & 85.2 & 7.6 \\
\hline Poland & na & na & 70.0 & 6.0 \\
\hline Portugal & 98.6 & 5.7 & 68.5 & 9.0 \\
\hline Slovak Republic & 96.4 & 4.2 & 89.4 & 5.7 \\
\hline Spain & 88.1 & 4.9 & 71.7 & 7.5 \\
\hline Sweden & 97.0 & 6.5 & 85.0 & 8.4 \\
\hline Switzerland & 92.8 & 5.7 & 55.6 & 10.7 \\
\hline Turkey & na & na & na & na \\
\hline United Kingdom & 86.1 & 5.3 & 80.9 & 7.3 \\
\hline United States & 68.2 & 7.0 & 44.2 & 13.1 \\
\hline OECD countries & 88.4 & 5.5 & 72.2 & 8.0 \\
\hline EU countries & 92.4 & 5.4 & 74.7 & 8.0 \\
\hline Minimum & 61.0 (Korea) & 4.0 (Greece) & 44.2 (US) & $\begin{array}{l}5.6 \text { (Mexico, } \\
\text { Luxembourg) }\end{array}$ \\
\hline Maximum & 98.7 (Norway) & 7.1 (Korea) & 91.4 (Czech Rep.) & 13.1 (US) \\
\hline
\end{tabular}

Sources: i) For health expenditure, OECD Health Data 2003 - Frequently asked data (http://www.oecd.org/document/16/0,2340,en_2825_495642_2085200_1_1_1_1,00.html. ii) For education expenditure, Education at a Glance 2003 - Tables, OECD (http://www.oecd.org/document/34/0,2340,en_2649_34515_14152482_1_1_1_1,00.html).

Notes: na-non available.

Public expenditure on education includes public subsidies to households attributable for educational institutions and direct expenditure on educational institutions from international sources.

Private expenditure on education is net of public subsidies attributable for educational institutions. 
In an environment of low growth and increased attention devoted by both the authorities and the public to government spending, the efficient allocation of resources in such growth promoting items as education and health seems therefore of paramount importance. Furthermore, and in what concerns the health sector, there is a genuine concern that for most OECD countries public spending in healthcare is bound to increase significantly in the next decades due to ageing related issues. Again, and since most of expenditure on healthcare comes from the public budget, how well these resources are used assumes increased relevance.

\section{Analytical methodology}

We apply two different non-parametric methods that allow the estimation of efficiency frontiers and efficiency losses - Free Disposable Hull (FDH) analysis and Data Envelopment Analysis (DEA). Both these methods have originally been developed and applied to firms that convert inputs into outputs. Coelli, Rao and Battese (1998), Sengupta (2000) and Simar and Wilson (2003) introduce the reader to this literature and describe several applications. The term "firm", sometimes replaced by a more encompassing "decision making unit", may include non-profit or public organisations, such as hospitals, schools or local authorities. For instance, De Borger and Kerstens (1996) analyse the efficiency of Belgian local governments, Coelli (1996) assesses the efficiency performance of Australian universities, and Afonso and Fernandes (2003) study the efficiency of local municipalities in the Lisbon region.

\subsection{FDH framework}

We apply a so-called FDH analysis, which is a non-parametric technique first proposed by Deprins, Simar, and Tulkens (1984). Suppose that under efficient conditions, the education or health status of a population $i$, measured by an indicator $y_{i}$, the output, depends solely on education or health expenditure per habitant, $x_{i}$, the input: ${ }^{5}$

\footnotetext{
${ }^{5}$ The reader interested in FDH analysis may refer to Gupta and Verhoeven (2001) and to Simar and Wilson (2003).
} 


$$
y_{i}=F\left(x_{i}\right)
$$

If $y_{i}<F\left(x_{i}\right)$, it is said that country $i$ exhibits inefficiency. For the observed expense level, the actual output is smaller than the best attainable one. FDH is one of the different methods of estimating function $F$, the efficiency frontier.

In a simple example, four different countries display the following values for indicator $y$ and expense level $x$ :

Table 2. Fictitious values for countries A, B, C and D

\begin{tabular}{lcc}
\hline & Indicator & Expenditure \\
\hline Country A & 65 & 800 \\
Country B & 66 & 950 \\
Country C & 75 & 1000 \\
Country D & 70 & 1300 \\
\hline
\end{tabular}

Expenditure is lower in country A (800), and the output level is also the lowest (65). Country D exhibits the highest expenditure (1300), but it is country $C$ that attains the best level of output (75).

Country D may be considered inefficient, in the sense that it performs worse than country C. The latter achieves a better status with less expense. On the other hand, countries $\mathrm{A}, \mathrm{B}$ or $\mathrm{C}$ do not show as inefficient using the same criterion.

In FDH analysis, countries $\mathrm{A}, \mathrm{B}$ and $\mathrm{C}$ are supposed to be located on the efficiency frontier $^{6}$. This frontier takes the following form in this example:

$$
y=F(x)= \begin{cases}65, & 800 \leq x<950 \\ 66, & 950 \leq x<1000 \\ 75, & 1000 \leq x \leq 1300\end{cases}
$$

This function is represented in Figure 1.

\footnotetext{
${ }^{6}$ Of course, it could still be the case that there are inefficiencies in those countries, in the sense that they could improve outcomes without increasing resources used. The point here is that there are no other countries in the sample that provided evidence this is so. As in a court, a country is presumed efficient till inefficiency evidence is provided.
} 
Figure 1. FDH frontier

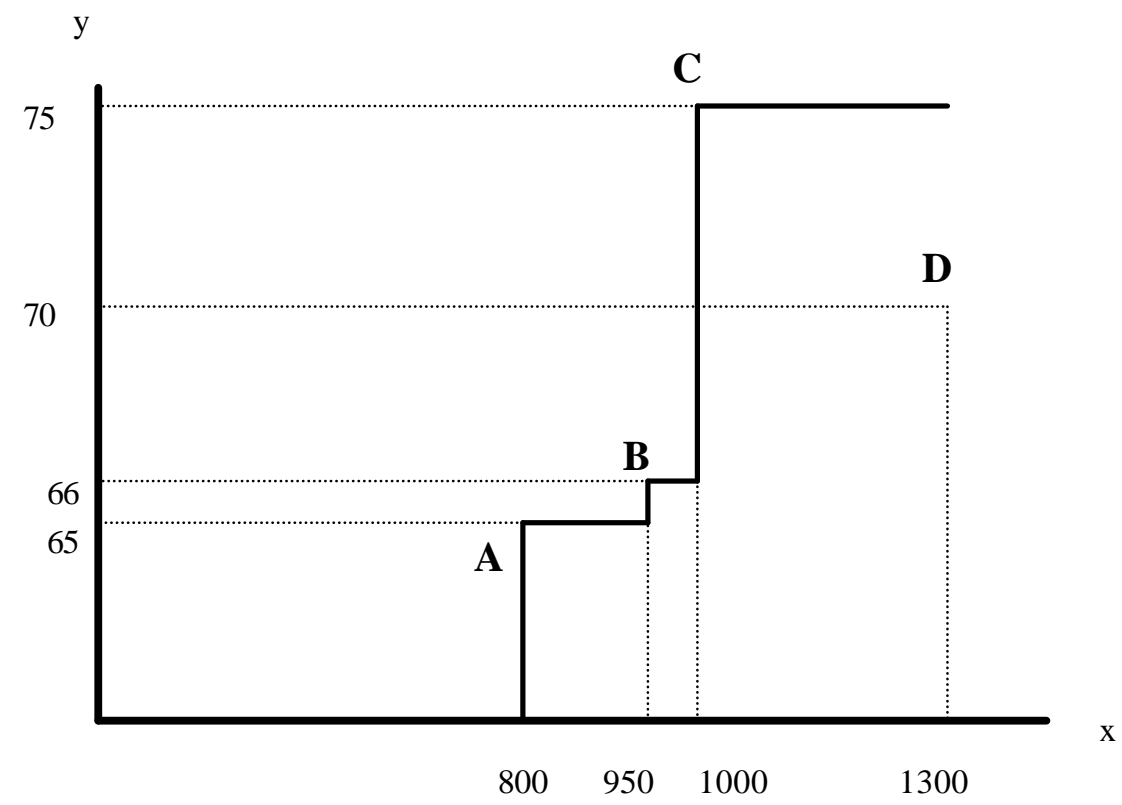

It is possible to measure country D inefficiency, or its efficiency scores, in two different ways:

i) Inefficiency may be measured as the vertical distance between point $\mathrm{D}$ and the efficiency frontier. Here, one is evaluating the difference between the output level that could have been achieved if all expense was applied in an efficient way, and the actual level of output. In this example, the efficiency loss equals 5 - country D should, at least, achieve the same indicator level as country $\mathrm{C}$, under efficient conditions.

ii) If one computes the horizontal distance to the frontier, the efficiency loss is now 300 , in units of expense. It can be said that efficiency losses in country D are about 24 percent $(=300 / 1300)$ of total expense. To attain an indicator level of 70 , it is necessary to spend no more than 1000 , as shown by country $\mathrm{C}$.

FDH analysis is also applicable in the multiple input-output cases. We sketch here how this is done, supposing the case of $k$ inputs, $m$ outputs and $n$ countries. ${ }^{7}$

\footnotetext{
${ }^{7}$ The interested reader may refer to Gupta and Verhoeven (2001) and to Simar and Wilson (2003).
} 
For country $i$, we select all countries that are more efficient - the ones that produce more of each output with less of each input. If no more efficient country is found, country $i$ is considered as an efficient one, and we assign unit input and output efficiency scores to it. If country $i$ is not efficient, its input efficiency score is equal to:

$$
\underset{n=n_{1}, \ldots, n_{l}}{\operatorname{MIN}} \underset{j=1, \ldots, k}{\operatorname{MAX}} \frac{x_{j}(n)}{x_{j}(i)}
$$

where $n_{1}, \ldots, n_{l}$ are the $l$ countries that are more efficient than country $i$.

The output efficiency score is calculated in a similar way and is equal to:

$$
\underset{n=n_{1}, \ldots, n_{l}}{\operatorname{MIN}} \underset{j=1, \ldots, m}{\operatorname{MAX}} \frac{y_{j}(i)}{y_{j}(n)} .
$$

Following the input and output scores calculation, countries can be ranked accordingly. Efficient countries are the same in both the input and output perspective, but the ranking and the efficiency scores of inefficient countries is not necessarily similar from both points of view.

\subsection{DEA framework}

Data Envelopment Analysis, originating from Farrell (1957) seminal work and popularised by Charnes, Cooper and Rhodes (1978), assumes the existence of a convex production frontier, a hypothesis that is not required for instance in the FDH approach. The production frontier in the DEA approach is constructed using linear programming methods. The terminology "envelopment" stems out from the fact that the production frontier envelops the set of observations. ${ }^{8}$

Similarly to FDH, DEA allows the calculation of technical efficiency measures that can be either input or output oriented. The purpose of an input-oriented study is to

\footnotetext{
${ }^{8}$ Coelli et al. (1998), and Thanassoulis (2001) offer good introductions to the DEA methodology. For a more advanced text see Simar and Wilson (2003).
} 
evaluate by how much input quantity can be proportionally reduced without changing the output quantities. Alternatively, and by computing output-oriented measures, one could also try to assess how much output quantities can be proportionally increased without changing the input quantities used. The two measures provide the same results under constant returns to scale but give different values under variable returns to scale. Nevertheless, and since the computation uses linear programming, not subject to statistical problems such as simultaneous equation bias and specification errors, both output and input-oriented models will identify the same set of efficient/inefficient producers or Decision Making Units (DMUs). ${ }^{9}$

The analytical description of the linear programming problem to be solved, in the variable returns to scale hypothesis, is sketched below. Suppose there are $k$ inputs and $m$ outputs for $n$ DMUs. For the i-th DMU, $y_{i}$ is the column vector of the outputs and $x_{i}$ is the column vector of the inputs. We can also define $X$ as the $(k \times n)$ input matrix and $Y$ as the $(m \times n)$ output matrix. The DEA model is then specified with the following mathematical programming problem, for a given i-th DMU: ${ }^{10}$

$$
\begin{array}{ll}
\text { MIN }_{\theta, \lambda} \theta & \\
\text { s.to } & -y_{i}+Y \lambda \geq 0 \\
& \theta x_{i}-X \lambda \geq 0 \\
& n 1^{\prime} \lambda=1 \\
& \lambda \geq 0
\end{array} .
$$

In problem (3), $\theta$ is a scalar (that satisfies $\theta \leq 1$ ), more specifically it is the efficiency score that measures technical efficiency of unit $\left(x_{i}, y_{i}\right)$. It measures the distance between a decision unit and the efficiency frontier, defined as a linear combination of best practice observations. With $\theta<1$, the decision unit is inside the frontier (i.e. it is inefficient), while $\theta=1$ implies that the decision unit is on the frontier (i.e. it is efficient).

\footnotetext{
${ }^{9}$ In fact, and as mentioned namely by Coelli et al. (1998), the choice between input and output orientations is not crucial since only the two measures associated with the inefficient units may be different between the two methodologies.

${ }^{10}$ We simply present here the equivalent envelopment form, derived by Charnes et al. (1978), using the duality property of the multiplier form of the original programming model. See Coelli et al. (1998) for more details.
} 
The vector $\lambda$ is a $(n \times 1)$ vector of constants, which measures the weights used to compute the location of an inefficient DMU if it were to become efficient. The inefficient DMU would be projected on the production frontier as a linear combination, using those weights, of the peers of the inefficient DMU. The peers are other DMUs that are more efficient and therefore are used as references for the inefficient DMU.

$n 1$ is a n-dimensional vector of ones. The restriction $n 1^{\prime} \lambda=1$ imposes convexity of the frontier, accounting for variable returns to scale. Dropping this restriction would amount to admit that returns to scale were constant.

Notice that problem (3) has to be solved for each of the $n$ DMUs in order to obtain the $n$ efficiency scores.

Figure 2. DEA frontiers

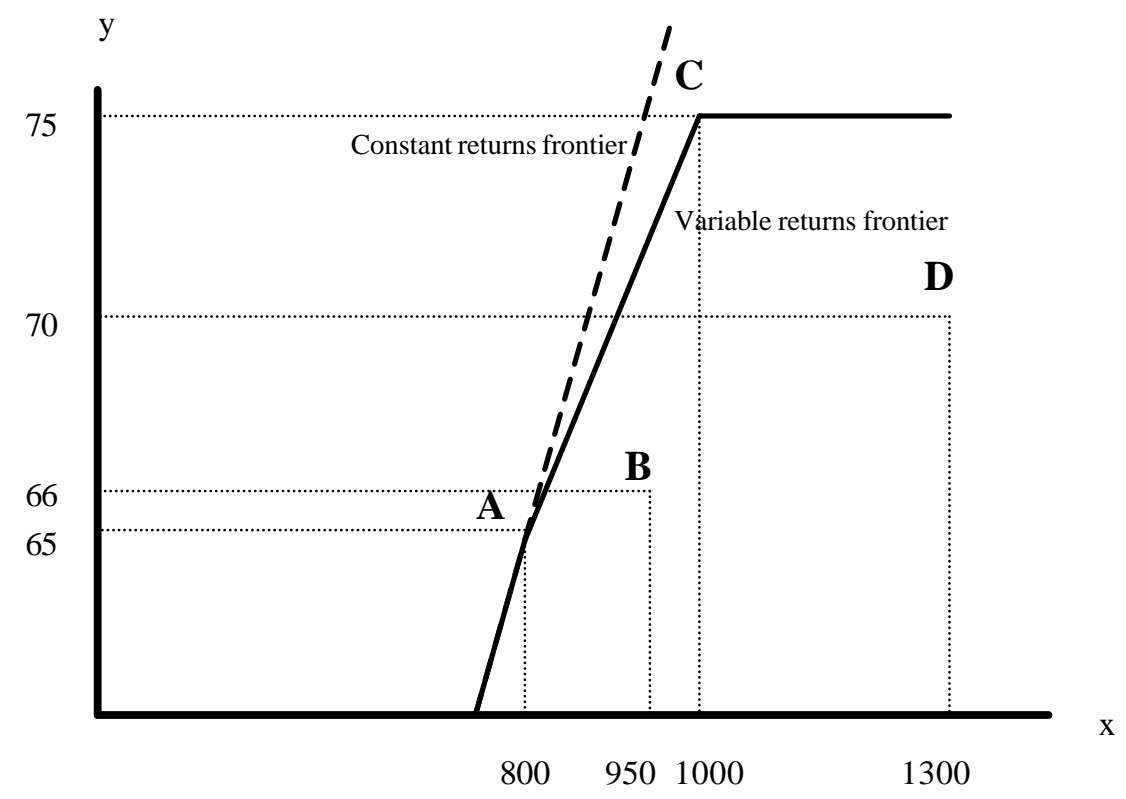

Figure 2 illustrates DEA frontiers with the very same invented data of Table 2. The variable returns to scale frontier unites the origin to point $\mathrm{A}$, and then point $\mathrm{A}$ to point C. If one compares this frontier to the FDH frontier in Figure 1, one notices that country B is now deemed inefficient. This results from the convexity restriction 
imposed when applying DEA. In fact, DEA is more stringent than FDH - a country that is efficient under FDH is not always efficient under DEA, but a country efficient under DEA will be efficient under FDH. In more general terms, input or output efficiency scores will be smaller with DEA.

The constant returns to scale frontier is represented in Figure 2 as a dotted line. In this one input - one output framework, this frontier is a straight line that passes through the origin and country A, where the output/input ratio is higher. Under this hypothesis, only one country is considered as efficient.

In the empirical analysis presented in this paper, the constant returns to scale hypothesis is never imposed. As a matter of fact, a priori conceptions about the shape of the frontier were kept to a minimum. Convexity is the only one considered here on top of the sensible efficiency concept embedded in FDH analysis.

\subsection{Some additional methodological issues}

Recently, some authors have applied the "education production function approach" to an international framework. Adapting from Barro and Lee (2001) and from Hanuschek and Luque (2002), the education production function can be specified as:

$$
y=G(r, f)+\varepsilon .
$$

where:

- $y$, a scalar, denotes the education outcome, or "school quality", measured by cross-country comparative studies assessing learning achievement;

- $r$, resources allocated to education;

- $f$, family factors that may affect the educational output, such as parents income or instruction level.

$-\varepsilon$ stands for other unmeasured factors with an influence on the outcome.

The function $G$ is assumed to be linear and is estimated by least squares methods.

Barro and Lee (2001) find that student performance is correlated to the level of school resources, such as pupil-teacher ratios, and also to family background (income and 
education of parents). For Hanuschek and Luque (2002), "the overall strength of resources in obtaining better student performance appears rather limited".

The "production function approach" posits that deviations from the function derive from unmeasured factors and have zero mean. The inefficiency concept is not embodied in the empirical method used. When there is no evidence of correlation between inputs and the outputs, then some inefficiency conclusions are drawn. In fact, if the DMUs, here countries, may exhibit inefficiency, then there is no necessary correlation between the inputs and the outputs. In empirical terms, it is perfectly possible to detect a pattern where more input does not generally translate into more output.

Our approach is essentially different from the production function one. We do not assume that all decision units operate on the production function. Moreover, our production function envelops our data and has no a priori functional form. Differently from the regression analysis, output may be measured by more than one variable. We intend to measure inefficiency, and not so much to explain it. In our analysis, we compare resources allocated to the health or education production processes to outcomes, and do not enter into account with some other factors that vary across countries and that may well be important for the achieved results, like the family factors mentioned above. Of course, these factors would become important candidate variables when it comes to explain measured inefficiencies, a logical research step to follow.

\section{Non-parametric efficiency analysis}

\subsection{Education indicators}

In what concerns education our main source of data is OECD (2002a). Input variables to be used are available there or can be constructed from raw data. Examples of possible output variables are graduation rates, and student mathematical, reading and scientific literacy indicators. Input variables may include not only expenditure per student, but also physical indicators such as the average class size, the ratio of 
students to teaching staff, number of instruction hours and the use and availability of computers. $^{11}$

Concerning education achievement we selected two frontier models: one model where the input is a financial variable and another version where we use only quantity explanatory variables as inputs. In both specifications, the output is measured by the performance of 15-year-olds on the PISA reading, mathematics and science literacy scales in 2000 (simple average of the three scores for each country). ${ }^{12}$

In the first specification, inputs are measured by the annual expenditure on educational institutions per student in equivalent US dollars converted using Purchasing Power Parities, in secondary education, based on full-time equivalents, 1999.

In the second specification, we use two quantitative input measures:

- the total intended instruction time in public institutions in hours per year for the 12 to 14-year-olds, 2000;

- the number of teachers per student in public and private institutions for secondary education, calculations based on full-time equivalents, 2000.

An obvious output measure for education attainment, the graduation rate, is unfortunately not very complete on the OECD source, and we decided not to use it.

\subsection{Education efficiency results}

Financial input results

Concerning the education performance for the secondary level in the OECD countries, we present in Table 3 the results of the FDH analysis using a single output, the PISA rankings for 2000, and a single input, annual expenditure per student in 1999.

\footnotetext{
${ }^{11}$ The data and the sources used in this paper are presented in the Annex. Note that total expenditure (public and private) was considered.

12 The three results in the PISA report are quite correlated, with the following correlation coeficients: $($ reading, mathematics $)=0.90,($ reading, science $)=0.82,($ mathematics, science $)=0.79$.
} 
Table 3. FDH Education efficiency scores: 1 input (annual expenditure on secondary education per student in 1999) and 1 output (PISA 2000 survey indicator)

\begin{tabular}{lccccc}
\hline \multirow{2}{*}{ Country } & \multicolumn{2}{c}{ Input efficiency } & \multicolumn{2}{c}{ Output efficiency } & Dominating \\
\cline { 2 - 5 } & Score & Rank & Score & Rank & producer * \\
\hline Australia & 0.499 & 14 & 0.975 & 9 & Korea/Japan \\
Austria & 0.402 & 20 & 0.946 & 12 & Korea/Japan \\
Belgium & 0.531 & 13 & 0.935 & 14 & Korea/Japan \\
Canada & 0.572 & 11 & 0.983 & 7 & Korea/Korea \\
Czech Republic & 0.991 & 6 & 0.924 & 17 & Korea/Korea \\
Denmark & 0.448 & 17 & 0.916 & 20 & Korea/Japan \\
Finland & 0.583 & 9 & 0.998 & 6 & Korea/Korea \\
France & 0.478 & 16 & 0.934 & 15 & Korea/Japan \\
Germany & 0.359 & 21 & 0.897 & 22 & Hungary/Japan \\
Greece & 0.545 & 12 & 0.943 & 13 & Poland/Hungary \\
Hungary & $\mathbf{1 . 0 0 0}$ & $\mathbf{1}$ & $\mathbf{1 . 0 0 0}$ & $\mathbf{1}$ & \\
Ireland & 0.780 & 7 & 0.950 & 10 & Korea/Korea \\
Italy & 0.243 & 24 & 0.872 & 23 & Poland/Japan \\
Japan & $\mathbf{1 . 0 0 0}$ & $\mathbf{1}$ & $\mathbf{1 . 0 0 0}$ & $\mathbf{1}$ & \\
Korea & $\mathbf{1 . 0 0 0}$ & $\mathbf{1}$ & $\mathbf{1 . 0 0 0}$ & $\mathbf{1}$ & \\
Mexico & $\mathbf{1 . 0 0 0}$ & $\mathbf{1}$ & $\mathbf{1 . 0 0 0}$ & $\mathbf{1}$ & \\
Norway & 0.448 & 18 & 0.923 & 18 & Korea/Japan \\
Poland & $\mathbf{1 . 0 0 0}$ & $\mathbf{1}$ & $\mathbf{1 . 0 0 0}$ & $\mathbf{1}$ & \\
Portugal & 0.306 & 23 & 0.842 & 24 & Poland/Korea \\
Spain & 0.487 & 15 & 0.899 & 21 & Hungary/Korea \\
Sweden & 0.578 & 10 & 0.947 & 11 & Korea/Korea \\
Switzerland & 0.350 & 22 & 0.933 & 16 & Korea/Japan \\
United Kingdom & 0.610 & 8 & 0.976 & 8 & Korea/Korea \\
United States & 0.419 & 19 & 0.918 & 19 & Korea/Japan \\
\hline Average & 0.610 & & 0.966 & & \\
\hline
\end{tabular}

* In terms of input efficiency/in terms of output efficiency.

From the results it is possible to conclude that five countries are located on the possibility production frontier: Hungary, Japan, Korea, Mexico, and Poland. Overall, average input efficiency is around 0.61 implying that on average countries in our sample might be able to achieve the same level of performance using only 61 per cent of the per capita expenditure they were using. In other words, there seems to be a "waste" of input resources of around 39 per cent on average.

The scope for input efficiency improvement is quite large since for some countries (Italy, Portugal) the input efficiency score is roughly half of the average score. For instance, countries such as Italy and Germany, where expenditure per student is above average, deliver a performance in secondary attainment below the average of the PISA index. 
Some important differences have to be mentioned when looking at the set of efficient countries in terms of education performance. Japan and Korea are located in the efficient frontier because they do indeed perform quite well in the PISA survey, getting respectively the first and the second position in the overall education performance index ranking. However, in terms of annual spending per student, Japan ranks above the average (6039 versus 5595 US dollars) and Korea (3419 US dollars) is clearly below average. ${ }^{13}$

On the other hand, countries like Mexico, Poland and Hungary are deemed efficient in the FDH analysis because they are quite below average in terms of spending per student. Given the expenditure allocated to education by these countries, their performance in the PISA index is not comparable to any other country with similar or inferior outcome and with less expenditure per student. Moreover, one has to note that Mexico, Poland and Hungary all have PISA outcomes below the country sample average. $^{14}$

In Table 4 we present the DEA variable-returns-to-scale technical efficiency results using the same one-input and one-output framework. We report for each country its peers, i.e. the countries that give the efficient production for each decision unit. ${ }^{15}$

\footnotetext{
${ }^{13}$ See Annex for details on the data.

${ }^{14}$ Notice that, by construction, the country that spends less is always on the frontier, even if its results are poor.

15 Additionally, and as a measure of comparison, we also present the constant returns to scale results. All the DEA computations of this paper were performed with the computer software DEAP 2.1 provided by Coelli et al (1998).
} 
Table 4. DEA results for education efficiency in OECD countries, 1 input (annual expenditure on secondary education per student in 1999) and 1 output (PISA 2000 survey indicator)

\begin{tabular}{lccccccc}
\hline \multirow{2}{*}{ Country } & \multicolumn{2}{c}{ Input oriented } & \multicolumn{2}{c}{ Output oriented } & & Peers & CRS TE \\
\cline { 2 - 5 } & VRS TE & Rank & VRS TE & Rank & & Input/output & \\
\hline Australia & 0.453 & 12 & 0.976 & 7 & & Korea, Poland/Japan & 0.257 \\
Austria & 0.311 & 17 & 0.947 & 11 & & Korea, Poland/Japan & 0.201 \\
Belgium & 0.384 & 14 & 0.936 & 13 & Korea, Poland/Japan & 0.262 \\
Canada & 0.528 & 11 & 0.98 & 6 & & Korea, Poland/Japan, Korea & 0.295 \\
Czech Republic & 0.650 & 6 & 0.924 & 16 & & Korea, Poland/Japan, Korea & 0.481 \\
Denmark & 0.283 & 20 & 0.915 & 19 & & Korea, Poland/Japan & 0.216 \\
Finland & 0.578 & 8 & 0.995 & 5 & & Korea, Poland/Japan, Korea & 0.306 \\
France & 0.342 & 16 & 0.934 & 14 & & Korea, Poland/Japan & 0.235 \\
Germany & 0.283 & 21 & 0.897 & 21 & & Korea, Poland/Japan & 0.245 \\
Greece & 0.533 & 10 & 0.879 & 22 & Mexico, Poland/Korea, Poland & 0.526 \\
Hungary & 0.802 & 5 & 0.968 & 9 & Korea, Poland/Korea, Poland & 0.684 \\
Ireland & 0.603 & 7 & 0.949 & 10 & & Korea, Poland/Japan & 0.389 \\
Italy & 0.242 & 24 & 0.871 & 23 & & Mexico, Poland/Japan & 0.241 \\
Japan & $\mathbf{1 . 0 0 0}$ & $\mathbf{1}$ & $\mathbf{1 . 0 0 0}$ & $\mathbf{1}$ & & Japan/Japan & 0.298 \\
Korea & $\mathbf{1 . 0 0 0}$ & $\mathbf{1}$ & $\mathbf{1 . 0 0 0}$ & $\mathbf{1}$ & & Korea/Korea & 0.525 \\
Mexico & $\mathbf{1 . 0 0 0}$ & $\mathbf{1}$ & $\mathbf{1 . 0 0 0}$ & $\mathbf{1}$ & & Mexico/Mexico & 0.962 \\
Norway & 0.298 & 18 & 0.923 & 17 & & Korea, Poland/Japan & 0.218 \\
Poland & $\mathbf{1 . 0 0 0}$ & $\mathbf{1}$ & $\mathbf{1 . 0 0 0}$ & $\mathbf{1}$ & & Poland/Poland & 1.000 \\
Portugal & 0.297 & 19 & 0.841 & 24 & Mexico, Poland/Japan, Korea & 0.292 \\
Spain & 0.384 & 15 & 0.898 & 20 & & Korea, Poland/Japan, Korea & 0.332 \\
Sweden & 0.443 & 13 & 0.945 & 12 & & Korea, Poland/Japan, Korea & 0.288 \\
Switzerland & 0.248 & 23 & 0.932 & 15 & & Korea, Poland/Japan & 0.172 \\
United Kingdom & 0.543 & 9 & 0.973 & 8 & & Korea, Poland/Japan, Korea & 0.312 \\
United States & 0.271 & 22 & 0.919 & 18 & & Korea, Poland/Japan & 0.203 \\
\hline Average & 0.520 & & 0.942 & & & 0.373 \\
\hline & & & & & & \\
\hline
\end{tabular}

Notes: CRS TE - constant returns to scale technical efficiency.

VRS TE - variable returns to scale technical efficiency.

It seems interesting to point out that in terms of variable returns to scale, the set of efficient countries that comes out from the DEA approach, Japan, Korea, Mexico and Poland, are basically the same countries that were on the production possibility frontier built previously with the FDH results. In the DEA analysis only Hungary is no longer efficient.

Using the results obtained from both DEA and FDH analysis, we constructed the production possibility frontiers for this set of OECD countries (see Figure 3), concerning spending per student and the PISA report outcomes. The graphical portray of the production possibility frontiers helps locating the countries in terms of distance from those frontiers. The dotted line represents the DEA frontier, while the full line stands for the FDH one. It is visually apparent how Hungary is dropped from the efficiency frontier when convexity is imposed. Notice that while some countries are 
positioned rather way from the frontier, such as the already mentioned cases of Portugal, Germany and Italy, other countries are relatively close to it, such as the Czech Republic, Finland, Australia or the UK.

Figure 3. Production possibility frontier, 24 OECD countries, 2000

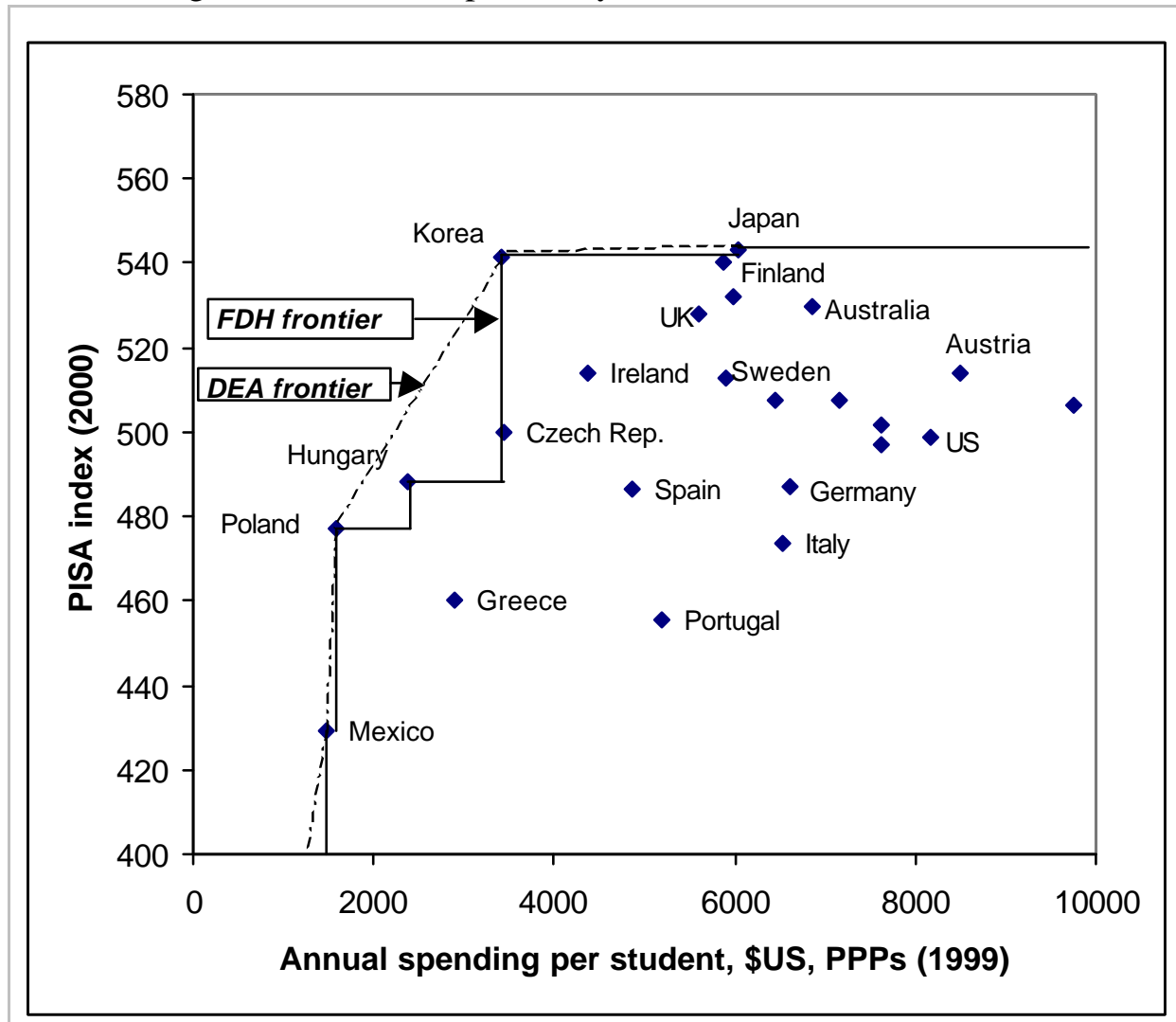

Results with quantitatively measured inputs

We broadened our education efficiency analysis by looking at quantity measures of inputs used to reach the recorded outcome of education secondary performance. This implied an alternative specification, still using the PISA index as the output but now with two input measures instead of one. These new input measures are the following quantity variables: number of hours per year spent in school and the number of teachers per student (see details in the Annex).

Since with these non-parametric approaches, higher performance is directly linked with higher input levels, we constructed the variable "Teachers Per Student," TPS, 


$$
T P S=\left(\frac{\text { Students }}{\text { Teachers }}\right)^{-1} \times 100,
$$

using the original information for the students-to-teachers ratio (see Annex). Naturally, one would expect education performance to increase with the number of teachers per student.

The results of the FDH analysis for this 2 inputs and 1 output alternative are reported in Table 5. We can observe that three of the countries that are now labelled as efficient, Japan, Korea, and Mexico, are precisely the same as before, when we used a financial measure as the sole input variable. However, now Hungary is no longer efficient, while Poland, another efficient country in the financial input set-up, was dropped from the sample due to the unavailability of data concerning the number of hours per year spent in school.

Table 5. FDH Education efficiency scores: 2 inputs (hours per year in school (2000), teachers per 100 students (2000)) and 1 output (PISA 2000 survey indicator)

\begin{tabular}{lccccc}
\hline \multirow{2}{*}{ Country } & \multicolumn{2}{c}{ Input efficiency } & \multicolumn{2}{c}{ Output efficiency } & Dominating \\
\cline { 2 - 5 } & Score & Rank & Score & Rank & producers * \\
\hline Australia & 0.850 & 13 & 0.975 & 7 & Korea/Japan \\
Belgium & 0.689 & 18 & 0.935 & 9 & Sweden/Japan \\
Czech Republic & 0.931 & 7 & 0.926 & 11 & Sweden/Finland \\
Denmark & 0.912 & 10 & 0.916 & 12 & Sweden/Japan \\
Finland & $\mathbf{1 . 0 0 0}$ & $\mathbf{1}$ & $\mathbf{1 . 0 0 0}$ & $\mathbf{1}$ & \\
France & 0.832 & 14 & 0.934 & 10 & Korea/Japan \\
Germany & 0.961 & 6 & 0.897 & 15 & Korea/Japan \\
Greece & 0.758 & 16 & 0.848 & 17 & Sweden/Japan \\
Hungary & 0.801 & 15 & 0.899 & 14 & Sweden/Japan \\
Italy & 0.730 & 17 & 0.872 & 16 & Sweden/Japan \\
Japan & $\mathbf{1 . 0 0 0}$ & $\mathbf{1}$ & $\mathbf{1 . 0 0 0}$ & $\mathbf{1}$ & \\
Korea & $\mathbf{1 . 0 0 0}$ & $\mathbf{1}$ & $\mathbf{1 . 0 0 0}$ & $\mathbf{1}$ & \\
Mexico & $\mathbf{1 . 0 0 0}$ & $\mathbf{1}$ & $\mathbf{1 . 0 0 0}$ & $\mathbf{1}$ & \\
New Zealand & 0.914 & 9 & 0.982 & 6 & Korea/Korea \\
Portugal & 0.879 & 11 & 0.844 & 18 & Sweden/Finland \\
Spain & 0.876 & 12 & 0.901 & 13 & Sweden/Finland \\
Sweden & $\mathbf{1 . 0 0 0}$ & $\mathbf{1}$ & $\mathbf{1 . 0 0 0}$ & $\mathbf{1}$ & \\
United Kingdom & 0.922 & 8 & 0.973 & 8 & Korea/Japan \\
\hline Average & 0.892 & & & 0939 & \\
\hline
\end{tabular}

* In terms of input efficiency/in terms of output efficiency.

Mexico is still deemed efficient essentially due to the fact that it has the highest students-to-teachers ratio in the country sample. On the other hand Hungary has now 
worse efficiency rankings and is dominated by Sweden and by Japan, that have a lower number of hours per year spent in school and a higher students-to-teachers ratio. Furthermore, both Japan and Sweden had a better performance outcome than Hungary in the PISA education index. Additionally, Sweden and Finland now come up as efficient since they have a students per teacher ratio not very different from the average, they are below average in terms of hours per year spent in school, and are above average concerning the PISA index ranking.

Therefore, this supplementary set of results, using quantity measures as inputs instead of a financial measure, seems to better balance the relative importance of the inputs used by each country. Indeed, it seems natural that in more developed countries like Sweden and Finland the cost of resources is higher than in less developed countries like Hungary and Mexico. Both Sweden and Finland were being somehow penalised when only a financial input was being used but this bias can be corrected using quantity measures as inputs.

Additionally, this set of results also reveals a higher average input efficiency score than before, placing the average "wasted" resources at a lower threshold of around 11 per cent. Concerning the average output efficiency score the results are nevertheless similar either using a financial input measure or two quantity input measures.

In Table 6 we report similar DEA variable-returns-to-scale technical efficiency results for 2 inputs and 1 output case.

With these quantity inputs one notices that three countries are still labelled efficient as before (DEA with 1 input and 1 output) assuming variable returns to scale: Japan, Korea, and Mexico. However, now two new countries appear as well as efficient, Sweden and Finland, in line with the results we obtained with the FDH analysis. Again Poland was dropped from the sample due to data unavailability and Hungary is once more no longer located on the frontier. 
Table 6. DEA results for education efficiency in OECD countries, 2 inputs (hours per year in school and teachers per 100 students) and 1 output (PISA survey indicator)

\begin{tabular}{|c|c|c|c|c|c|c|}
\hline \multirow[t]{2}{*}{ Country } & \multicolumn{2}{|c|}{ Input oriented } & \multicolumn{2}{|c|}{ Output oriented } & \multirow{2}{*}{$\begin{array}{c}\text { Peers } \\
\text { Input/output }\end{array}$} & \multirow[t]{2}{*}{ CRS TE } \\
\hline & VRS TE & Rank & VRS TE & Rank & & \\
\hline Australia & 0.788 & 14 & 0.976 & 7 & Sweden, Finland, Korea/Japan & 0.783 \\
\hline Belgium & 0.689 & 18 & 0.936 & 9 & Sweden, Korea/Japan & 0.683 \\
\hline Czech Republic & 0.880 & 6 & 0.921 & 11 & Sweden, Korea/Japan, Finland & 0.849 \\
\hline Denmark & 0.857 & 12 & 0.915 & 12 & Sweden, Korea/Japan & 0.823 \\
\hline Finland & 1.000 & 1 & 1.000 & 1 & Finland/Finland & 0.981 \\
\hline France & 0.762 & 15 & 0.934 & 10 & Sweden, Korea/Japan & 0.736 \\
\hline Germany & 0.891 & 6 & 0.897 & 15 & Sweden, Korea/Japan & 0.823 \\
\hline Greece & 0.715 & 17 & 0.847 & 17 & Sweden, Korea/Japan & 0.636 \\
\hline Hungary & 0.801 & 13 & 0.899 & 13 & Sweden/Japan & 0.762 \\
\hline Italy & 0.728 & 16 & 0.871 & 16 & Sweden, Korea/Japan & 0.671 \\
\hline Japan & 1.000 & 1 & 1.000 & $\mathbf{1}$ & Japan/Japan & 0.942 \\
\hline Korea & 1.000 & 1 & 1.000 & 1 & Korea/Korea & 1.000 \\
\hline Mexico & 1.000 & 1 & 1.000 & 1 & Mexico/Mexico & 1.000 \\
\hline New Zealand & 0.878 & 9 & 0.979 & 6 & Sweden, Korea/Japan, Finland & 0.874 \\
\hline Portugal & 0.880 & 8 & 0.842 & 18 & Sweden/Japan, Finland & 0.782 \\
\hline Spain & 0.877 & 10 & 0.899 & 14 & Sweden/Japan, Finland & 0.832 \\
\hline Sweden & 1.000 & 1 & 1.000 & 1 & Sweden/Sweden & 1.000 \\
\hline United Kingdom & 0.859 & 11 & 0.972 & 8 & Sweden, Finland, Korea/Japan & 0.859 \\
\hline Average & 0.867 & & 0.938 & & & 0.835 \\
\hline
\end{tabular}

Notes: CRS TE - constant returns to scale technical efficiency. VRS TE - variable returns to scale technical efficiency.

\subsection{Health indicators}

OECD (2000b) is our chosen health database for OECD countries. Typical input variables include in-patient beds, medical technology indicators and health employment. Output is to be measured by indicators such as life expectancy and infant and maternal mortality, in order to assess potential years of added life.

It is of course difficult to measure something as complex as the health status of a population. We have not innovated here, and took two usual measures of health attainment, infant mortality and life expectancy. ${ }^{16}$

Efficiency measurement techniques used in this paper imply that outputs are measured in such a way that "more is better." This is clearly not the case with infant mortality. Recall that the Infant Mortality Rate (IMR) is equal to:

\footnotetext{
${ }^{16}$ These health measures, or similar ones, have been used in other studies on health and public expenditure efficiency - see Afonso, Schuknecht and Tanzi (2003), Evans, Tandon, Murray and Lauer (2000), Gupta and Verhoeven (2001) and St. Aubyn (2002).
} 
(Number of children who died before 12 months)/(Number of born children) $\times 1000$.

We have calculated an "Infant Survival Rate", ISR,

$$
I S R=\frac{1000-I M R}{I M R}
$$

which has two nice properties: it is directly interpretable as the ratio of children that survived the first year to the number of children that died; and, of course, it increases with a better health status.

We have chosen to measure health spending in per capita terms and in purchasing power parities, therefore allowing for the fact that poorer countries spend less in real and per capita terms, even if their health spending is hypothetically comparable to richer nations when measured as a percentage of GDP ${ }^{17}$.

Therefore, our first frontier model for health has two outputs:

- the infant survival rate,

- and life expectancy,

the input being per capita health expenditure in purchasing power parities.

In a second formulation, and following the same reasoning that was made for education, we compared physically measured inputs to outcomes. In our second frontier model for health are the same as before. Quantitative inputs are the number of doctors, of nurses and of in-patient beds per thousand habitants.

\footnotetext{
${ }^{17}$ As with education, total expenditure (public and private) was considered. See the Annex for data details.
} 


\subsection{Health efficiency results}

Financial input results

Results using input measured in monetary terms are a tentative answer to the following questions: do countries that spend more on health attain a better health status for their population? Or else are there a number of countries that spend comparatively more on health without an improved result?

Table 7. FDH Health efficiency scores: 1 input (per capita total health expenditure) and 2 outputs (infant survival rate and life expectancy)

\begin{tabular}{|c|c|c|c|c|c|}
\hline \multirow[t]{2}{*}{ Country } & \multicolumn{2}{|c|}{ Input efficiency } & \multicolumn{2}{|c|}{ Output efficiency } & \multirow{2}{*}{$\begin{array}{l}\text { Dominating } \\
\text { producers * }\end{array}$} \\
\hline & Score & Rank & Score & Rank & \\
\hline Australia & 0.843 & 18 & 0.981 & 16 & Japan \\
\hline Austria & 0.882 & 15 & 0.969 & 22 & Japan \\
\hline Belgium & 0.689 & 24 & 0.964 & 27 & Spain/Japan \\
\hline Canada & 0.759 & 22 & 0.981 & 17 & Japan \\
\hline Czech Republic & 1.000 & 1 & 1.000 & 1 & \\
\hline Denmark & 0.682 & 25 & 0.952 & 29 & Finland/Japan \\
\hline Finland & 1.000 & 1 & 1.000 & 1 & \\
\hline France & 0.823 & 20 & 0.979 & 18 & Japan \\
\hline Germany & 0.565 & 29 & 0.965 & 26 & Spain/Japan \\
\hline Greece & 1.000 & 1 & 1.000 & 1 & \\
\hline Hungary & 0.839 & 19 & 0.936 & 30 & Korea \\
\hline Iceland & 1.000 & 1 & 1.000 & 1 & \\
\hline Ireland & 0.878 & 17 & 0.972 & 21 & Spain \\
\hline Italy & 0.780 & 21 & 0.975 & 19 & Spain/Japan \\
\hline Japan & 1.000 & 1 & 1.000 & 1 & \\
\hline Korea & 1.000 & 1 & 1.000 & 1 & \\
\hline Luxembourg & 0.586 & 28 & 0.969 & 23 & Spain/Japan \\
\hline Mexico & 1.000 & 1 & 1.000 & 1 & \\
\hline Netherlands & 0.678 & 26 & 0.968 & 24 & Spain/Japan \\
\hline New Zealand & 0.954 & 14 & 0.995 & 13 & Spain \\
\hline Norway & 0.717 & 23 & 0.974 & 20 & Japan \\
\hline Poland & 1.000 & 1 & 1.000 & 1 & \\
\hline Portugal & 1.000 & 1 & 1.000 & 1 & \\
\hline Slovak Republic & 0.983 & 13 & 0.967 & 25 & Korea \\
\hline Spain & 1.000 & 1 & 1.000 & 1 & \\
\hline Sweden & 0.993 & 12 & 1.000 & 12 & Japan \\
\hline Switzerland & 0.588 & 27 & 0.990 & 14 & Japan \\
\hline Turkey & 1.000 & 1 & 1.000 & 1 & \\
\hline United Kingdom & 0.881 & 16 & 0.983 & 15 & Spain \\
\hline United States & 0.313 & 30 & 0.953 & 28 & Greece/Japan \\
\hline Average & 0.848 & & 0.982 & & \\
\hline
\end{tabular}

Table 7 displays FDH results when a financial input, total per capita expenditure, is considered. In 30 considered countries, 11 were estimated to be on the efficiency 
frontier - the Czech Republic, Finland, Greece, Iceland, Japan, Korea, Mexico, Poland, Portugal, Spain and Turkey.

Note again that, by construction, the country that spends less is always on the frontier, even if its results are poor. This is why Mexico and Turkey are considered here as efficient, as both spend clearly below average and have results also clearly below average.

Another group of countries located in the frontier is the "less than average spenders" that attains "average to good results." Here, we can include the Czech Republic, Greece, Korea, Portugal and Spain. Finally, Finland, Iceland and Japan belong to a third group - those that have very good results without spending that much.

If we analyse the inefficient group of countries, the ones not in the FDH frontier, a number of countries display strong spending inefficiency. The United States have an input efficiency score of 0.313 with Greece as a reference, meaning that Greece spends less than a third of what the US spends, having better results. From this point of view, the US wastes more than two thirds of its spending. Similarly, Spain, an efficient country, spends slightly more than half $(56,5 \%)$ of German expenditure, being better off. Germany therefore is estimated to waste $43,5 \%$ of its spending.

Results for this 1 input -2 output model using DEA are summarised is Table 8 . 
Table 8. DEA results for health efficiency in OECD countries, 1 input (per capita total expenditure in health) and 2 outputs (infant survival rate and life expectancy)

\begin{tabular}{|c|c|c|c|c|c|c|}
\hline \multirow[t]{2}{*}{ Country } & \multicolumn{2}{|c|}{ Input oriented } & \multicolumn{2}{|c|}{ Output oriented } & \multirow{2}{*}{$\begin{array}{c}\text { Peers } \\
\text { Input/output }\end{array}$} & \multirow[t]{2}{*}{ CRS TE } \\
\hline & VRS TE & Rank & VRS TE & Rank & & \\
\hline Australia & 0.670 & 17 & 0.981 & 13 & Japan, Mexico/Japan & 0.385 \\
\hline Austria & 0.634 & 19 & 0.969 & 20 & Czech Republic, Japan, Korea/Japan & 0.502 \\
\hline Belgium & 0.556 & 25 & 0.964 & 25 & Czech Republic, Japan, Korea/Japan & 0.447 \\
\hline Canada & 0.604 & 21 & 0.981 & 14 & Japan, Mexico/Japan & 0.369 \\
\hline Czech Republic & 1.000 & 1 & 1.000 & 1 & Czech Republic/Czech Republic & 1.000 \\
\hline Denmark & 0.526 & 26 & 0.952 & 29 & Czech Republic, Japan, Korea/Japan & 0.462 \\
\hline Finland & 0.906 & 10 & 0.981 & 15 & $\begin{array}{l}\text { Czech Republic, Iceland, Japan/ } \\
\text { Czech Republic, Iceland, Japan }\end{array}$ & 0.768 \\
\hline France & 0.641 & 18 & 0.979 & 16 & Korea, Japan, Mexico/Japan & 0.479 \\
\hline Germany & 0.490 & 29 & 0.965 & 24 & Czech Republic, Japan, Korea/Japan & 0.395 \\
\hline Greece & 0.892 & 12 & 0.992 & 9 & Japan, Mexico/Japan, Mexico & 0.564 \\
\hline Hungary & 0.757 & 14 & 0.928 & 30 & $\begin{array}{l}\text { Czech Republic, Poland/ } \\
\text { Japan, Korea, Mexico }\end{array}$ & 0.751 \\
\hline Iceland & 1.000 & 1 & 1.000 & 1 & Iceland/Iceland & 0.823 \\
\hline Ireland & 0.591 & 22 & 0.958 & 27 & $\begin{array}{l}\text { Czech Republic, Japan, Korea/ } \\
\text { Japan, Mexico }\end{array}$ & 0.515 \\
\hline Italy & 0.711 & 15 & 0.975 & 17 & Japan, Mexico/Japan & 0.490 \\
\hline Japan & 1.000 & 1 & 1.000 & 1 & Japan/Japan & 0.737 \\
\hline Korea & 1.000 & 1 & 1.000 & $\mathbf{1}$ & Korea/Korea & 0.973 \\
\hline Luxembourg & 0.511 & 28 & 0.969 & 21 & Czech Republic, Japan, Korea/Japan & 0.402 \\
\hline Mexico & 1.000 & 1 & 1.000 & 1 & Mexico/Mexico & 0.839 \\
\hline Netherlands & 0.559 & 24 & 0.968 & 22 & Japan, Korea, Mexico/Japan & 0.419 \\
\hline New Zealand & 0.837 & 13 & 0.987 & 12 & Japan, Mexico/Japan, Mexico & 0.571 \\
\hline Norway & 0.580 & 23 & 0.974 & 18 & Czech Republic, Japan, Korea/Japan & 0.460 \\
\hline Poland & 1.000 & 1 & 1.000 & 1 & Poland/Poland & 1.000 \\
\hline Portugal & 0.628 & 20 & 0.959 & 26 & $\begin{array}{l}\text { Czech Republic, Japan, Korea/ } \\
\text { Japan, Mexico }\end{array}$ & 0.593 \\
\hline Slovak Republic & 0.895 & 11 & 0.966 & 23 & $\begin{array}{l}\text { Czech Republic, Poland/ } \\
\text { Japan, Korea, Mexico }\end{array}$ & 0.895 \\
\hline Spain & 0.955 & 8 & 0.996 & 8 & Japan, Korea, Mexico/Japan, Mexico & 0.700 \\
\hline Sweden & 0.948 & 9 & 0.988 & 11 & $\begin{array}{l}\text { Czech Republic, Iceland, Japan/ } \\
\text { Czech Republic, Iceland, Japan }\end{array}$ & 0.732 \\
\hline Switzerland & 0.523 & 27 & 0.990 & 10 & Japan, Mexico/Japan & 0.323 \\
\hline Turkey & 1.000 & 1 & 1.000 & 1 & Turkey/Turkey & 1.000 \\
\hline United Kingdom & 0.672 & 16 & 0.972 & 19 & Japan, Korea, Mexico/Japan, Mexico & 0.509 \\
\hline United States & 0.206 & 30 & 0.953 & 28 & Japan, Korea, Mexico/Japan & 0.157 \\
\hline Average & 0.743 & & 0.978 & & & 0.609 \\
\hline
\end{tabular}

Notes: CRS TE - constant returns to scale technical efficiency.

VRS TE - variable returns to scale technical efficiency.

In general terms, DEA results are not very different from FDH ones, the efficient group of countries being a subset of those previously efficient under FDH analysis. Specifically, Finland, Greece, Portugal and Spain are now inefficient, and the Czech Republic, Iceland, Japan, Korea, Mexico, Poland and Turkey define the frontier. The most striking difference is for Portugal - under DEA, this country is now near the end of the ranking, either in terms of input or output scores. Indeed, Portugal is dominated 
by the Czech Republic, Korea, and Japan, the first two countries having lower per capita spending in health and similar life expectancy.

Results with quantitatively measured inputs

When using quantitatively measured inputs, we are simply comparing resources available to the health sector (doctors, nurses, beds) with outcomes, without controlling for the cost of those resources. It is therefore possible that a country is efficient under this framework, but not in a model where spending is the input.

Table 9. FDH Health efficiency scores: 3 inputs (doctors, nurses and beds) and 2 outputs (infant mortality and life expectancy)

\begin{tabular}{|c|c|c|c|c|c|}
\hline \multirow[t]{2}{*}{ Country } & \multicolumn{2}{|c|}{ Input efficiency } & \multicolumn{2}{|c|}{ Output efficiency } & \multirow{2}{*}{$\begin{array}{l}\text { Dominating } \\
\text { producers * }\end{array}$} \\
\hline & Score & Rank & Score & Rank & \\
\hline Australia & 0.926 & 18 & 1.000 & 14 & Canada \\
\hline Austria & 0.967 & 16 & 0.981 & 19 & Sweden \\
\hline Canada & 1.000 & 1 & 1.000 & 1 & \\
\hline Czech Republic & 1.000 & 15 & 0.949 & 21 & France \\
\hline Denmark & 1.000 & 1 & 1.000 & 1 & \\
\hline Finland & 0.935 & 17 & 0.974 & 20 & Sweden \\
\hline France & 1.000 & 1 & 1.000 & 1 & \\
\hline Germany & 0.935 & 24 & 0.949 & 24 & Sweden \\
\hline Greece & 0.923 & 19 & 0.992 & 16 & Spain \\
\hline Hungary & 0.663 & 26 & 0.913 & 26 & Korea/Spain \\
\hline Ireland & 0.902 & 25 & 0.946 & 25 & Canada \\
\hline Italy & 0.837 & 22 & 0.997 & 15 & Spain \\
\hline Japan & 1.000 & 1 & 1.000 & 1 & \\
\hline Korea & 1.000 & 1 & 1.000 & 1 & \\
\hline Luxembourg & 1.000 & 14 & 0.991 & 18 & Spain \\
\hline Mexico & 1.000 & 1 & 1.000 & 1 & \\
\hline Netherlands & 0.935 & 23 & 0.974 & 22 & Sweden \\
\hline New Zealand & 0.913 & 20 & 0.991 & 17 & Canada \\
\hline Norway & 1.000 & 1 & 1.000 & 1 & \\
\hline Poland & 0.902 & 21 & 0.946 & 23 & United Kingdom \\
\hline Portugal & 1.000 & 1 & 1.000 & 1 & \\
\hline Spain & 1.000 & 1 & 1.000 & 1 & \\
\hline Sweden & 1.000 & 1 & 1.000 & 1 & \\
\hline Turkey & 1.000 & 1 & 1.000 & 1 & \\
\hline United Kingdom & 1.000 & 1 & 1.000 & 1 & \\
\hline United States & 1.000 & 1 & 1.000 & 1 & \\
\hline Average & 0.959 & & 0.987 & & \\
\hline
\end{tabular}

* In terms input efficiency/in terms of output efficiency.

Half among the 26 countries analysed with this second formulation for health was estimated as efficient under FDH analysis (see Table 9). These are Canada, Denmark, France, Japan, Korea, Mexico, Norway, Portugal, Spain, Sweden, Turkey, the United 
Kingdom and the United States. Again one can distinguish different reasons for being considered efficient. Some countries have few resources allocated to health with corresponding low results (Mexico, Turkey); a second group attains better than average results with lower than average resources (e.g. the United Kingdom); finally, there is a third group of countries which are very good performers (e.g. Japan and Sweden).

Table 10. DEA results for health efficiency in OECD countries, 3 inputs (doctors, nurses and beds) and 2 outputs (infant mortality and life expectancy)

\begin{tabular}{|c|c|c|c|c|c|c|}
\hline \multirow[t]{2}{*}{ Country } & \multicolumn{2}{|c|}{ Input oriented } & \multicolumn{2}{|c|}{ Output oriented } & \multirow{2}{*}{$\begin{array}{c}\text { Peers } \\
\text { Input/output }\end{array}$} & \multirow[t]{2}{*}{ CRS TE } \\
\hline & VRS TE & Rank & VRS TE & Rank & & \\
\hline Australia & 0.832 & 11 & 0.990 & 12 & $\begin{array}{l}\text { Canada, Japan, Spain, United Kingdom/ } \\
\text { Canada, Japan, Spain, Sweden }\end{array}$ & 0.691 \\
\hline \multirow{4}{*}{$\begin{array}{l}\text { Austria } \\
\text { Canada } \\
\text { Czech Republic } \\
\text { Denmark }\end{array}$} & 0.703 & 21 & 0.976 & 15 & Japan, Korea, Sweden/Japan, Sweden & 0.703 \\
\hline & 1.000 & 1 & 1.000 & 1 & Canada & 0.978 \\
\hline & 0.681 & 22 & 0.936 & 24 & Japan, Korea, Sweden/Japan, Sweden & 0.675 \\
\hline & 0.808 & 14 & 0.965 & 21 & $\begin{array}{l}\text { Korea, Mexico, Spain, Sweden/ } \\
\text { Japan, Spain, Sweden }\end{array}$ & 0.802 \\
\hline \multirow{2}{*}{$\begin{array}{l}\text { Finland } \\
\text { France }\end{array}$} & 0.806 & 15 & 0.970 & 19 & Japan, Korea, Sweden/Japan, Sweden & 0.802 \\
\hline & 0.835 & 10 & 0.991 & 10 & $\begin{array}{l}\text { Japan, Korea, Spain, Sweden, United Kingdom/ } \\
\text { Japan, Spain, Sweden }\end{array}$ & 0.768 \\
\hline \multirow{3}{*}{$\begin{array}{l}\text { Germany } \\
\text { Greece } \\
\text { Hungary }\end{array}$} & 0.604 & 24 & 0.972 & 18 & Japan, Korea, Sweden/Japan, Sweden & 0.604 \\
\hline & 0.820 & 13 & 0.991 & 11 & Korea, Mexico, Spain/Japan, Spain, Sweden & 0.695 \\
\hline & 0.480 & 26 & 0.892 & 26 & $\begin{array}{l}\text { Korea, Mexico, Turkey, United Kingdom/ } \\
\text { Japan, Spain }\end{array}$ & 0.460 \\
\hline \multirow{5}{*}{$\begin{array}{l}\text { Ireland } \\
\text { Italy } \\
\text { Japan } \\
\text { Korea } \\
\text { Luxembourg }\end{array}$} & 0.716 & 19 & 0.958 & 23 & Japan, Korea, Sweden/Canada, Japan, Sweden & 0.715 \\
\hline & 0.798 & 16 & 0.995 & 9 & Mexico, Spain, Sweden/Japan, Spain, Sweden & 0.743 \\
\hline & 1.000 & 1 & 1.000 & $\mathbf{1}$ & Japan & 1.000 \\
\hline & 1.000 & $\mathbf{1}$ & 1.000 & $\mathbf{1}$ & Korea & 1.000 \\
\hline & 0.707 & 20 & 0.979 & 14 & $\begin{array}{l}\text { Japan, Korea, Spain, Sweden, United Kingdom/ } \\
\text { Japan, Spain, Sweden }\end{array}$ & 0.683 \\
\hline \multirow{2}{*}{$\begin{array}{l}\text { Mexico } \\
\text { Netherlands }\end{array}$} & 1.000 & 1 & 1.000 & 1 & Mexico & 1.000 \\
\hline & 0.579 & 25 & 0.973 & 17 & $\begin{array}{l}\text { Canada, Japan, Korea, United Kingdom/ } \\
\text { Japan, Sweden }\end{array}$ & 0.577 \\
\hline New Zealand & 0.830 & 12 & 0.986 & 13 & $\begin{array}{l}\text { Canada, Japan, Korea, United Kingdom/ } \\
\text { Canada, Japan, Sweden }\end{array}$ & 0.802 \\
\hline \multirow{2}{*}{$\begin{array}{l}\text { Norway } \\
\text { Poland }\end{array}$} & 0.726 & 17 & 0.976 & 16 & Japan, Korea, Sweden/Japan, Sweden & 0.725 \\
\hline & 0.679 & 23 & 0.934 & 25 & $\begin{array}{l}\text { Mexico, Turkey, United Kingdom/ } \\
\text { Canada, Japan, Spain, United Kingdom }\end{array}$ & 0.675 \\
\hline Portugal & 0.844 & 9 & 0.961 & 22 & $\begin{array}{l}\text { Korea, Mexico, Spain, Sweden/ } \\
\text { Mexico, Spain, Sweden }\end{array}$ & 0.836 \\
\hline Spain & 1.000 & 1 & 1.000 & 1 & Spain & 1.000 \\
\hline Sweden & 1.000 & 1 & 1.000 & 1 & Sweden & 1.000 \\
\hline Turkey & 1.000 & 1 & 1.000 & $\mathbf{1}$ & Turkey & 1.000 \\
\hline \multirow{2}{*}{$\begin{array}{l}\text { United Kingdom } \\
\text { United States }\end{array}$} & 1.000 & 1 & 1.000 & 1 & United Kingdom & 1.000 \\
\hline & 0.725 & 18 & 0.968 & 20 & $\begin{array}{l}\text { Mexico, Sweden, United Kingdom/ } \\
\text { Canada, Mexico, Sweden }\end{array}$ & 0.724 \\
\hline Average & 0.814 & & 0.977 & & & 0.795 \\
\hline
\end{tabular}

Notes: CRS TE - constant returns to scale technical efficiency. VRS TE - variable returns to scale technical efficiency.

Again, under DEA, the efficient group is smaller than under FDH. DEA results are summarised in Table 10, and there are 8 countries in the frontier: Canada, Japan, 
Korea, Mexico, Spain, Sweden, Turkey and the United Kingdom. All these countries were already considered efficient under FDH, but half of the "FDH-efficient" nations are not efficient now (Denmark, France, Norway, Portugal, Spain, Sweden, Turkey, and the United States). It is interesting to note that a group of ex-communist countries and European Union 2004 newcomers (the Czech Republic, Hungary, Poland) are among the less efficient in providing health, when resources are physically measured.

\section{Conclusion}

We summarise in Table 11 the results, for both sectors and for both methods, using the different input and output measures, in terms of the countries that we found out as being efficient.

Table 11. OECD efficient countries in education and in health sectors: two non-parametric approaches and different input and output measures

\begin{tabular}{|c|c|c|c|}
\hline Sector & Inputs, Outputs & $\begin{array}{c}\text { Non-parametric } \\
\text { method }\end{array}$ & Countries \\
\hline \multirow{4}{*}{ Education } & \multirow[t]{2}{*}{$\begin{array}{l}\text { - Spending per student (in) } \\
\text { - PISA (out) }\end{array}$} & FDH & $\begin{array}{l}\text { Japan, Korea, Mexico, } \\
\text { Poland, Hungary }\end{array}$ \\
\hline & & DEA & $\begin{array}{l}\text { Japan, Korea, Mexico, } \\
\text { Poland }\end{array}$ \\
\hline & \multirow{2}{*}{$\begin{array}{l}\text { - Hours per year in school (in) } \\
\text { - Teachers per } 100 \text { students (in) } \\
\text { - PISA (out) }\end{array}$} & $\mathrm{FDH}$ & $\begin{array}{l}\text { Japan, Korea, Mexico, } \\
\text { Sweden, Finland } \\
\end{array}$ \\
\hline & & DEA & $\begin{array}{l}\text { Japan, Korea, Mexico, } \\
\text { Sweden, Finland }\end{array}$ \\
\hline \multirow{4}{*}{ Health } & \multirow[t]{2}{*}{$\begin{array}{l}\text { - Per capita health spending (in) } \\
\text { - Life expectancy (out) } \\
\text { - Infant mortality (out) }\end{array}$} & $\mathrm{FDH}$ & $\begin{array}{l}\text { Czech Republic, Finland, } \\
\text { Greece, Iceland, Japan, } \\
\text { Korea, Mexico, Poland, } \\
\text { Portugal, Spain, Turkey }\end{array}$ \\
\hline & & DEA & $\begin{array}{l}\text { Czech Republic, Iceland, } \\
\text { Japan, Korea, Mexico, } \\
\text { Poland, Turkey }\end{array}$ \\
\hline & \multirow{2}{*}{$\begin{array}{l}\text { - Doctors (in) } \\
\text { - Nurses (in) } \\
\text { - Hospital beds (in) } \\
\text { - Life expectancy (out) } \\
\text { - Infant mortality (out) }\end{array}$} & FDH & $\begin{array}{l}\text { Canada, Denmark, France, } \\
\text { Japan, Korea, Mexico, } \\
\text { Norway, Portugal, Spain, } \\
\text { Sweden, Turkey, UK, US }\end{array}$ \\
\hline & & DEA & $\begin{array}{l}\text { Canada, Japan, Korea, } \\
\text { Mexico, Spain, Sweden, } \\
\text { Turkey, UK }\end{array}$ \\
\hline
\end{tabular}

The results from our empirical work in evaluating efficiency in health and education expenditure allow: 
i) computing efficiency measures for each country in producing health and education, with corresponding estimates of efficiency losses, therefore identifying the most efficient cases;

ii) a comparison across methods (DEA and FDH), evaluating result robustness;

iii) a comparison between efficiency when financial cost is considered and efficiency when inputs are physically measured;

iv) a comparison across the two sectors, education and health, to see whether efficiency and inefficiency are country specific.

Our results strongly suggest that efficiency in spending in these two economic sectors where public provision is usually very important is not an issue to be neglected. In the education sector, the average input inefficiency varies between 0.520 (1 input, 1 output, DEA) and 0.892 (2 inputs, 1 output, FDH), depending on the model and method, and on health, it varies between 0.743 ( 1 input, 2 outputs, DEA) and 0.959 (3 inputs, 2 outputs, FDH). Consequently, in less efficient countries there is scope for attaining better results using the very same resources.

Results using DEA were broadly comparable to results using FDH. DEA is more stringent, in the sense that a country that is efficient under DEA is also efficient under $\mathrm{FDH}$, the reverse not being true.

Measuring efficiency when one considers the financial resources allocated to a sector is different from assessing efficiency from the measurement of resources in physical terms. The case of Sweden clearly illustrates this point. This is a country that only arises as efficient, in both education and health sectors, when inputs are physically measured. In our interpretation, this may well result from the fact that resources are comparatively expensive in Sweden. An opposite example is provided by the twin cases of the Czech Republic and Poland in what concerns health and by Hungary and Poland in the education sector. They are not efficient in physical terms. Probably because resources considered (doctors, nurses, hospital beds, teachers) are comparatively cheaper, they become efficient in financial terms. 
Some countries appear as efficient no matter what method, model or sector is considered - Mexico, Japan and Korea. Mexico is the country that spends fewer resources in these sectors and also gets the worse results. It appears as efficient for this sole reason. Japan and Korea are different cases. Japan is the best performer in health and education as far as outputs are concerned, and does not spend too many resources. Korea is a very good education performer, and it spends very little on health with surprisingly good results in comparative terms.

We evaluated efficiency across countries in two sectors, essentially comparing resources to outputs. This opens the way to a different but related line of research, which is to explain why some countries are more efficient than others when it comes to education or health provision. Different plausible linkages can be investigated. We point out some, to suggest some future research:

- As an important part of education or health expenditure and provision is public, it could be the case that inefficient provision is related to public sector inefficiency;

- Other differences across countries can play a role in explaining our results. For example, a different population density or composition may well imply different needs from an input perspective in order to attain the same measured outputs. Also, different levels of GDP per head or of educational attainment by the adult population could imply different outcomes in health or education, even under efficient public services ${ }^{18}$.

- Countries are also different in what concerns the mix of public and private funding of education and health (see Table 1). One possible source of inefficiency could derive from the interaction between these.

Clearly, and after measuring efficiency, identifying the (in)efficiency sources would be of great importance in economic policy terms.

\footnotetext{
${ }^{18}$ As mentioned before in the main text, Barro and Lee (2001), with different countries, data and time period, found a statistically significant influence of these two variables on student achievement.
} 


\section{References}

Afonso, A. and Fernandes, S. (2003). "Efficiency of Local Government Spending: Evidence for the Lisbon Region," ISEG-UTL, Department of Economics, Working Paper $n^{\circ}$ 9/2003/DE/CISEP.

Afonso, A.; Schuknecht, L. and Tanzi, V. (2003). "Public Sector Efficiency: An International Comparison," ECB Working Paper nº 242.

Barro, R. and J-W Lee (2001). "Schooling Quality in a Cross-Section of Countries", Economica, 68, 465-488.

Charnes, A.; Cooper, W. and Rhodes, E. (1978). "Measuring the efficiency of decision making units," European Journal of Operational Research, 2 (6), 429-444.

Clements, B. (2002). "How Efficient is Education Spending in Europe?" European Review of Economics and Finance, 1(1), 3-26.

Coelli, T. (1996). "Assessing the Performance of Australian Universities using Data Envelopment Analysis," mimeo, University of New England.

Coelli, T.; Rao, P. and Battese, G. (1998). An Introduction to Efficiency and Productivity Analysis. Kluwer, Boston.

De Borger, B. and Kerstens, K. (1996). "Cost Efficiency of Belgian Local Governments: A Comparative Analysis of FDH, DEA, and Econometric Approaches," Regional Science and Urban Economics, 26(2), 145-170.

Deprins, D., Simar, L., and Tulkens, H. (1984). "Measuring labor-efficiency in post offices," in: Marchand, M.; Pestieau, P. and Tulkens, H. (Eds.), The performance of public enterprises: concepts and measurement. Amsterdam: North-Holland.

Evans, D., Tandon, A.; Murray, C. and Lauer, J. (2000). "The Comparative Efficiency of National Health Systems in Producing Health: an Analysis of 191 Countries," GPE Discussion Paper Series 29, World Health Organisation, Geneva.

Fakin, B. and de Crombrugghe, A. (1997). "Fiscal Adjustment in Transition Economies: Social Transfers and the Efficiency of Public Spending, a Comparison with OECD Countries," Policy Research Working Paper 1803, The World Bank, Washington.

Farrell, M. (1957). "The Measurement of Productive Efficiency," Journal of the Royal Statistical Society, Series A, 120, Part 3, 253-290.

Gupta, S. and Verhoeven, M. (2001). "The Efficiency of Government Expenditure Experiences from Africa", Journal of Policy Modelling, 23, 433-467.

Hanushek, E. and J. Luque (2002). Efficiency and Equity in Schools Around the World, WP 8949, National Bureau of Economic Research, Cambridge, USA. 
OECD (2001). Knowledge and Skills for Life - First Results from Pisa 2000, Paris.

OECD (2002a). Education at a Glance - OECD Indicators 2002, OECD, Paris.

OECD (2002b). OECD Health Data 2002, OECD, Paris.

Sengupta, J. (2000). Dynamic and Stochastic Efficiency Analysis - Economics of Data Envelopment Analysis, World Scientific, Singapore.

Simar, L. and Wilson, P. (2003). Efficiency analysis: the statistical approach, lecture notes, July.

St. Aubyn, M. (2002). "Evaluating Efficiency in the Portuguese Health and Education Sectors," paper presented to the conference "Desenvolvimento Económico Português no Espaço Europeu: Determinantes e Políticas", Banco de Portugal, May, Fundação Calouste Gulbenkian, Lisbon.

St. Aubyn, M. (2003). "Evaluating efficiency in the Portuguese education sector", Economia, forthcoming.

Thanassoulis, E. (2001). Introduction to the Theory and Application of Data Envelopment Analysis, Kluwer Academic Publishers. 


\section{Annex - Data and sources}

Table A1. Education indicators

\begin{tabular}{|c|c|c|c|c|}
\hline Country & $\begin{array}{c}\text { PISA (2000) } \\
1 / \\
\end{array}$ & $\begin{array}{l}\text { Spending per } \\
\text { student } 2 /\end{array}$ & $\begin{array}{c}\text { Hours per year } \\
\text { in school 3/ }\end{array}$ & $\begin{array}{c}\text { Students per } \\
\text { teacher } 4 /\end{array}$ \\
\hline Australia & 530 & 6850 & 1019 & 12.6 \\
\hline Austria & 514 & 8504 & 1148 & \\
\hline Belgium & 508 & 6444 & 1075 & 9.7 \\
\hline Canada & 532 & 5981 & & 18.8 \\
\hline Czech Republic & 500 & 3449 & 867 & 13.1 \\
\hline Denmark & 497 & 7626 & 890 & 12.8 \\
\hline Finland & 540 & 5863 & 808 & 13.8 \\
\hline France & 507 & 7152 & 1042 & 12.5 \\
\hline Germany & 487 & 6603 & 903 & 15.2 \\
\hline Greece & 460 & 2904 & 1064 & 10.7 \\
\hline Hungary & 488 & 2368 & 925 & 11.2 \\
\hline Iceland & 506 & & 809 & \\
\hline Ireland & 514 & 4383 & 891 & \\
\hline Italy & 473 & 6518 & 1020 & 10.3 \\
\hline Japan & 543 & 6039 & 875 & 15.2 \\
\hline Korea & 541 & 3419 & 867 & 21.2 \\
\hline Luxembourg & 436 & & & 9.2 \\
\hline Mexico & 429 & 1480 & 1167 & 31.7 \\
\hline Netherlands & & & 1067 & 17.1 \\
\hline New Zealand & 531 & & 948 & 16.3 \\
\hline Norway & 501 & 7628 & 827 & \\
\hline Poland & 477 & 1583 & & 15.5 \\
\hline Portugal & 456 & 5181 & 842 & 9.0 \\
\hline Slovak Republic & & & & 13.2 \\
\hline Spain & 487 & 4864 & 845 & 11.9 \\
\hline Sweden & 513 & 5911 & 741 & 14.1 \\
\hline Switzerland & 506 & 9756 & & \\
\hline Turkey & & & 796 & 14.0 \\
\hline United Kingdom & 528 & 5608 & 940 & 14.8 \\
\hline United States & 499 & 8157 & & 15.2 \\
\hline Mean & 500 & 5595 & 932 & 14.4 \\
\hline Median & 506 & 5946 & 897 & 13.8 \\
\hline Minimum & 429 & 1480 & 741 & 9.0 \\
\hline Maximum & 543 & 9756 & 1167 & 31.7 \\
\hline Standard deviation & 30 & 2186 & 117 & 4.6 \\
\hline Observations & 27 & 24 & 24 & 25 \\
\hline
\end{tabular}

1/ Average of performance of 15 -year-olds on the PISA reading, mathematics and science literacy scales, 2000. Source: OECD (2001).

2/ Annual expenditure on educational institutions per student in equivalent US dollars converted using PPPs, secondary education, based on full-time equivalents, 1999. Source: OECD (2002a).

3/ Total intended instruction time in public institutions in hours per year for 12 to 14-year-olds, 2000. Source: OECD (2002a).

4/ Ratio of students to teaching staff in public and private institutions, secondary education, calculations based on full-time equivalents, 2000. Source: OECD (2002a). 
Table A2. Health indicators

\begin{tabular}{|c|c|c|c|c|c|c|}
\hline Country & $\begin{array}{c}\text { Life } \\
\text { expectancy } 1 /\end{array}$ & $\begin{array}{c}\text { Infant } \\
\text { mortality } 2 /\end{array}$ & $\begin{array}{c}\text { Per capita } \\
\text { spending in } \\
\text { health } 3 /\end{array}$ & Doctors 4/ & Nurses 5/ & $\begin{array}{c}\text { Hospital beds } \\
6 /\end{array}$ \\
\hline Australia & 79.0 & 5.7 & 2058 & 2.5 & 8.1 & 7.9 \\
\hline Austria & 78.0 & 4.4 & 1968 & 3.0 & 9.0 & 8.8 \\
\hline Belgium & 77.6 & 4.9 & 2008 & 3.8 & & 7.3 \\
\hline Canada & 79.0 & 5.3 & 2285 & 2.1 & 7.5 & 3.9 \\
\hline Czech Republic & 74.8 & 4.6 & 944 & 3.0 & 8.2 & 8.7 \\
\hline Denmark & 76.6 & 4.2 & 2241 & 3.4 & 7.3 & 4.5 \\
\hline Finland & 77.4 & 3.7 & 1529 & 3.1 & 14.4 & 7.6 \\
\hline France & 78.8 & 4.3 & 2109 & 3 & 6 & 8.4 \\
\hline Germany & 77.7 & 4.5 & 2451 & 3.5 & 9.5 & 9.2 \\
\hline Greece & 78.1 & 6.2 & 1307 & 4.4 & 3.9 & 4.9 \\
\hline Hungary & 70.7 & 8.4 & 751 & 3.2 & 5.0 & 8.3 \\
\hline Iceland & 79.5 & 2.4 & 2204 & 3.4 & 14.2 & \\
\hline Ireland & 76.5 & 5.5 & 1576 & 2.3 & 8.7 & 9.7 \\
\hline Italy & 78.5 & 5.1 & 1774 & 5.9 & 4.5 & 4.9 \\
\hline Japan & 80.5 & 3.4 & 1735 & 1.9 & 7.8 & 16.4 \\
\hline Korea & 75.5 & 7.7 & 630 & 1.3 & 1.4 & 5.5 \\
\hline Luxembourg & 78.0 & 4.6 & 2361 & 3.1 & 7.1 & 8 \\
\hline Mexico & 75.0 & 25.9 & 431 & 1.7 & 1.2 & 1.1 \\
\hline Netherlands & 77.9 & 5.2 & 2040 & 3.1 & 12.7 & 11.1 \\
\hline New Zealand & 78.3 & 5.4 & 1450 & 2.3 & 9.6 & 6.2 \\
\hline Norway & 78.4 & 3.9 & 2421 & 2.8 & 10.1 & 14.4 \\
\hline Poland & 73.2 & 8.9 & 543 & 2.3 & 5.1 & 5.1 \\
\hline Portugal & 75.6 & 5.6 & 1345 & 3.2 & 3.8 & 4 \\
\hline Slovak Republic & 73.0 & 8.3 & 641 & & 7.3 & 8.1 \\
\hline Spain & 78.7 & 4.5 & 1384 & 3.1 & 3.6 & 4.1 \\
\hline Sweden & 79.5 & 3.4 & 1748 & 2.9 & 8.4 & 3.7 \\
\hline Switzerland & 79.7 & 4.6 & 2952 & 3.4 & & 18.3 \\
\hline Turkey & 68.4 & 40.3 & 303 & 1.2 & 1.1 & 2.6 \\
\hline United Kingdom & 77.4 & 5.8 & 1527 & 1.8 & 4.6 & 4.1 \\
\hline United States & 76.7 & 7.1 & 4178 & 2.8 & 8.3 & 3.6 \\
\hline Mean & 76.9 & 7.1 & 1696.5 & 2.9 & 7.1 & 7.3 \\
\hline Median & 77.8 & 5.2 & 1741.5 & 3.0 & 7.4 & 7.3 \\
\hline Minimum & 68.4 & 2.4 & 303.0 & 1.2 & 1.1 & 1.1 \\
\hline Maximum & 80.5 & 40.3 & 4178.0 & 5.9 & 14.4 & 18.3 \\
\hline Standard deviation & 2.7 & 7.5 & 827.6 & 0.9 & 3.5 & 4.0 \\
\hline Observations & 30 & 30 & 30 & 29 & 28 & 29 \\
\hline
\end{tabular}

1/ Years of life expectancy. Total population at birth. 1999. Greece: 1998. Italy: 1997. Source: OECD (2002b).

2/ Deaths per 1000 live births. 1999. Korea: 1997. New Zealand: 1998. Source: OECD (2002b).

3/ Total expenditure on health per capita, purchasing power parities, US dollars. 1998. Source: OECD (2002b).

4/ Practising physicians, density per 1000 population. 1999. Australia, France and Japan: 1998. Source: OECD (2002b).

5/ Practising nurses, density per 1000 population. 1999. Australia, France: 1997. Japan: 1998. Slovakia: 2000. Source: OECD (2002b).

6/ Total in patient care beds per 1000 population. 1999. Denmark, Ireland, Luxembourg, New Zealand, Portugal: 1998. Belgium: 1997. Source: OECD (2002b). 